\title{
Microstructural Investigations of Rapidly Solidified Al-Co-Y Alloys
}

\author{
B. Avar, ${ }^{1}$ M. Gogebakan, ${ }^{2}$ M. Tarakci, ${ }^{3}$ Y. Gencer, ${ }^{3}$ and S. Kerlii \\ ${ }^{1}$ Department of Metallurgical Engineering, Bulent Ecevit University, Incivez, 67100 Zonguldak, Turkey \\ ${ }^{2}$ Department of Physics, Faculty of Arts and Sciences, Kahramanmaras Sutcu Imam University, 46100 Kahramanmaras, Turkey \\ ${ }^{3}$ Department of Materials Science and Engineering, Gebze Institute of Technology, Gebze, 41400 Kocaeli, Turkey
}

Correspondence should be addressed to B. Avar; barisavar@beun.edu.tr

Received 4 May 2013; Revised 2 August 2013; Accepted 16 August 2013

Academic Editor: Amit Bandyopadhyay

Copyright (C) 2013 B. Avar et al. This is an open access article distributed under the Creative Commons Attribution License, which permits unrestricted use, distribution, and reproduction in any medium, provided the original work is properly cited.

\begin{abstract}
The alloys with different compositions in the Al-rich corner of the Al-Co-Y ternary system were prepared by conventional casting and further processed by melt-spinning technique. The microstructure and the thermal behavior of the alloys were analyzed by means of X-ray diffraction (XRD), scanning electron microscopy (SEM), differential scanning calorimetry (DSC), and differential thermal analysis (DTA). It was found that only rapidly solidified $\mathrm{Al}_{85} \mathrm{Co}_{7} \mathrm{Y}_{8}$ alloy exhibited the best glass forming ability (GFA) and a fully amorphous structure. Besides, $\mathrm{Al}_{85} \mathrm{Co}_{13} \mathrm{Y}_{2}$ and $\mathrm{Al}_{85} \mathrm{Co}_{2} \mathrm{Y}_{13}$ alloy ribbons were fully crystalline, whereas $\mathrm{Al}_{85} \mathrm{Co}_{10} \mathrm{Y}_{5}$ and $\mathrm{Al}_{85} \mathrm{Co}_{5} \mathrm{Y}_{10}$ alloy ribbons consisted of some crystalline phases within an amorphous matrix. The SEM results showed the same trend that the crystalline phase fraction decreases with the approaching into best glass former. From DSC results, only $\mathrm{Al}_{85} \mathrm{Co}_{7} \mathrm{Y}_{8}$ amorphous alloy exhibited a glass transition temperature $\left(T_{g}\right)$ at $569 \mathrm{~K}$, and its supercooled liquid region $\left(\Delta T_{x}=T_{x}-T_{g}\right)$ was found to be $17 \mathrm{~K}$. Moreover, other calculated GFA parameters for this alloy system were also discussed.
\end{abstract}

\section{Introduction}

Because of their remarkable mechanical properties, which are useful for industrial and structural applications, Al-based amorphous alloys with high $\mathrm{Al}$ content (>80 at.\%) have attracted considerable attention $[1,2]$. In recent years, a series of investigations on the formation, structure, and properties of Al-based amorphous alloys have been carried out with an aim of developing high-strength materials with good ductility and high corrosion resistance [2-6]. So far, various Al-based amorphous alloys have been produced by rapid solidification processing. Among them, Al-TM-RE alloys (TM: transition metal, RE: rare earth metal) and their derivations, such as Al$\mathrm{Ni}-\mathrm{Y}$ [2, 7-9], and Al-Ni-La [10-12], and Al-Ni-Y-Co [13-15], have been intensively studied with regard to the formation and stability of the amorphous phase. It was reported that Al-Ni-Y ternary amorphous alloys exhibit better mechanical properties, and their thermal stability and glass forming ability (GFA) can be substantially improved with the addition of Co. And it has been found that quaternary $\mathrm{Al}_{85} \mathrm{Ni}_{5} \mathrm{Y}_{8} \mathrm{Co}_{2}$ (at.\%) alloy has the highest GFA in Al-based amorphous alloys [13]. That is why the investigations on components of Al-based amorphous alloys are focused on the Al-Ni-Y ternary system. On the other hand, just a few works have been reported for the other ternary system, Al-Co-Y alloys. In 1988, Inoue et al. [16] were the first to report that the amorphous phase was formed in the range of 2-17 at.\% $\mathrm{Y}$ and 4-18 at.\% Co for the Al-Co-Y system. Latuch and Dmowski [17] investigated the crystallization of $\mathrm{Al}_{85} \mathrm{Y}_{10} \mathrm{TM}_{5}$ ( $\mathrm{TM}=\mathrm{Fe}, \mathrm{Co}, \mathrm{Ni}$, and $\mathrm{Cu}$ ) amorphous ribbons. Three stages of crystallization were observed in amorphous $\mathrm{Al}_{85} \mathrm{Y}_{10} \mathrm{Co}_{5}$ alloy, which correspond to the formation of fcc- $\mathrm{Al}, \mathrm{Al}_{3} \mathrm{Y}$, $\mathrm{Al}_{9} \mathrm{Co}_{2}$, and some unidentified phases. Yang et al. [18] investigated the GFA of $\mathrm{Al}_{100-3 x} \mathrm{Co}_{x} \mathrm{Y}_{2 x}(x=3.5-6)$ and $\mathrm{Al}_{100-2 x} \mathrm{Co}_{x} \mathrm{Y}_{x}(x=4-9)$ melt-spun alloys. The best glass former $\mathrm{Al}_{88} \mathrm{Co}_{4} \mathrm{Y}_{8}$ with a thickness of $200 \mu \mathrm{m}$ was found by monitoring the microstructure evolutions in the $\mathrm{Al}-\mathrm{Al}_{3} \mathrm{Y}$ $\mathrm{Al}_{9} \mathrm{Co}_{2}$ ternary zone. Furthermore, Dong et al. $[19,20]$ also investigated the glass formability in the melt-spun Al-Co$\mathrm{Y}$ alloys by the microstructure evolution and reported that 


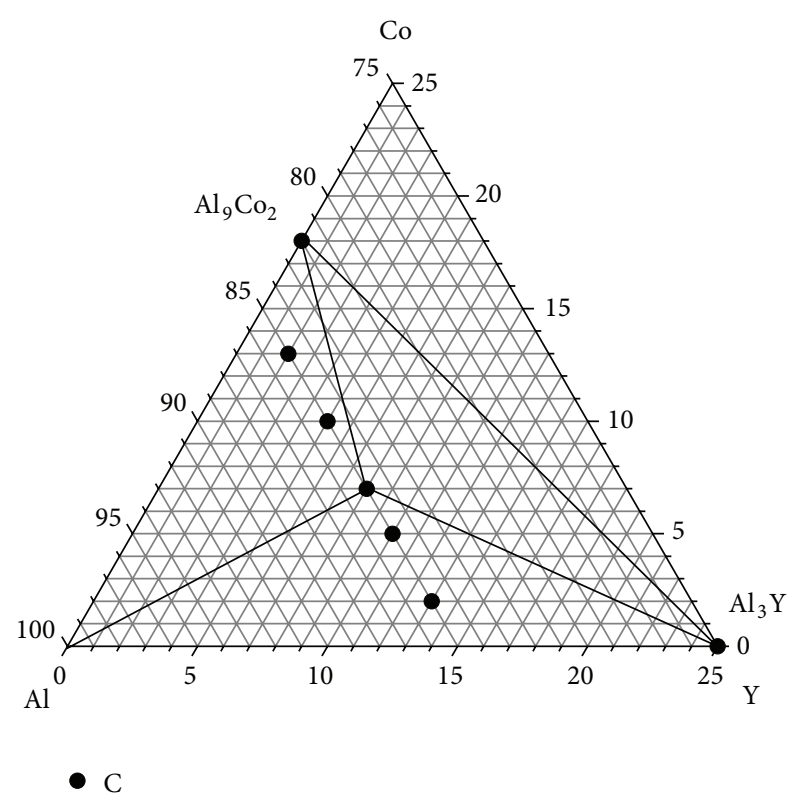

FIGURE 1: Al-Co-Y ternary phase diagram showing alloy compositions studied in this research.

$\mathrm{Al}_{88} \mathrm{Co}_{5} \mathrm{Y}_{7}$ alloy with the thickness of $230 \mu \mathrm{m}$ has the best GFA of the Al-Co-Y ternary systems. Comparisons of these composition alloys indicated that the GFA of Al-Co-Y alloy system is more sensitive to the replacement between alloy elements. Tiny change of the composition caused dramatic changes in the GFA of Al-Co-Y alloy, resulting in the differences of the microstructure and the thermal stability. Moreover, these results exhibited that by monitoring the microstructural changes, the best glass forming composition could be successfully found in the given alloy system. Such a strategy was carried out in pinpointing the best glass forming composition of $\mathrm{Cu}_{64.5} \mathrm{Zr}_{35.5}$ in a binary $\mathrm{Cu}-\mathrm{Zr}$ system [21], and $\mathrm{Zr}_{48} \mathrm{Cu}_{45} \mathrm{Al}_{7}$ in a ternary $\mathrm{Zr}-\mathrm{Cu}-\mathrm{Al}$ system [22] prepared by the copper mold casting method. Unfortunately, contrary to common observation, the best glass formers $\mathrm{Al}_{88} \mathrm{Co}_{4} \mathrm{Y}_{8}$ and $\mathrm{Al}_{88} \mathrm{Co}_{5} \mathrm{Y}_{7}$ alloys did not present a supercooled liquid characteristic [18-20], which lead to the superplasticity and improved ductility. This indicates that the chemical interaction between $\mathrm{Al}$ and the alloying elements plays an essential role in the practical glass formability for the Al-based alloys [23]. Besides, the investigation of the glass formability of AlCo-Y ternary system in comparison with other Al-TM-RE systems is relatively few. On this basis, in the present study, we aimed to investigate the GFA, microstructure, and the thermal stability of the rapidly solidified $\mathrm{Al}_{85} \mathrm{Co}_{15-x} \mathrm{Y}_{x}(x=$ 2, 5, 8, 10, and 13 at.\%) alloys.

\section{Experimental}

The nominal compositions of the investigated alloys are $\mathrm{Al}_{85} \mathrm{Co}_{15-x} \mathrm{Y}_{x}(x=2,5,8,10$, and 13 at.\%). Designation of the studied alloy compositions and their locations in the Al-rich corner of Al-Co-Y ternary phase diagram are shown in Figure 1. As seen in Figure 1, the alloy compositions are

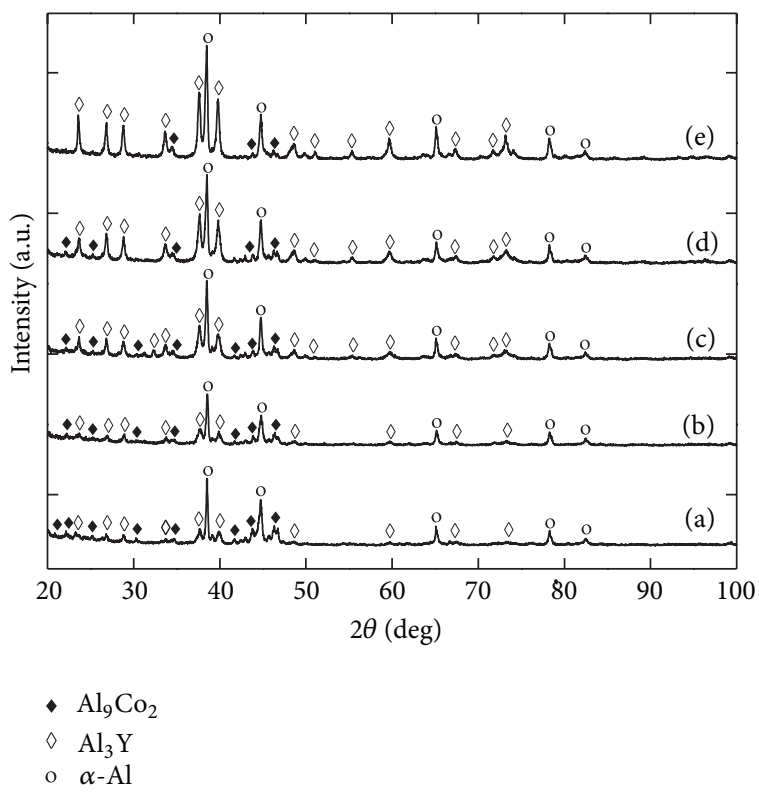

FIGURE 2: XRD patterns of Al-Co-Y master alloy ingots, (a) $\mathrm{Al}_{85} \mathrm{Co}_{13} \mathrm{Y}_{2}$, (b) $\mathrm{Al}_{85} \mathrm{Co}_{10} \mathrm{Y}_{5}$, (c) $\mathrm{Al}_{85} \mathrm{Co}_{7} \mathrm{Y}_{8}$, (d) $\mathrm{Al}_{85} \mathrm{Co}_{5} \mathrm{Y}_{10}$, and (e) $\mathrm{Al}_{85} \mathrm{Co}_{2} \mathrm{Y}_{13}$.

located in the ternary triangle zone $\mathrm{Al}-\mathrm{Al}_{9} \mathrm{Co}_{2}-\mathrm{Al}_{3} \mathrm{Y}$. The alloy ingots (10 g each) were prepared from high-purity elements by arc melting (Edmund Bühler, Arc-Melter MAM-1) under argon atmosphere. The melting process was repeated four times in order to obtain chemical homogeneity, and the weight loss was less than $1 \mathrm{wt} . \%$. Then, the alloy ingots were cut into suitably shaped pieces for the rapid solidification. Rapidly solidified ribbons were prepared by the single roller melt-spinning process (Edmund Bühler, Melt Spinner SC) with a copper wheel surface velocity of $30 \mathrm{~ms}^{-1}$ under argon atmosphere. The resulting melt-spun ribbons were typically $1.5-4 \mathrm{~mm}$ in width and $30-120 \mu \mathrm{m}$ in thickness. The phase identification of the conventional cast and rapidly solidified alloys were carried out by X-ray diffraction (XRD) using a Philips X'Pert powder diffractometer with $\mathrm{Cu}-\mathrm{K} \alpha$ radiation generated at $40 \mathrm{kV}$ and $30 \mathrm{~mA}$. The XRD analyses were performed from $20^{\circ}$ to $100^{\circ}(2 \theta)$ with a step size of $0.02^{\circ}$ and a count time of $1 \mathrm{~s}$ per step. The cross section of the ribbons was examined by a Zeiss Evo LS10 scanning electron microscope (SEM) with an energy-dispersive X-ray spectroscopy (EDX) analysis. Thermal behavior of the ribbons was studied by differential scanning calorimetry (Perkin-Elmer DSC 800) and differential thermal analysis (Perkin-Elmer Diamond DTA) at a heating rate of $20^{\circ} \mathrm{C} \mathrm{min}^{-1}$ under dynamic nitrogen atmosphere.

\section{Results and Discussion}

The phase constitutions of the conventional ingot alloys were identified by XRD analysis. Figure 2 shows the peaks obtained in the analysis compared with the JCPDS database [24]. The XRD patterns indicate that Al-Co-Y ingot alloys have three different phases, $\alpha$-Al solid solution, intermetallic $\mathrm{Al}_{3} \mathrm{Y}$, 


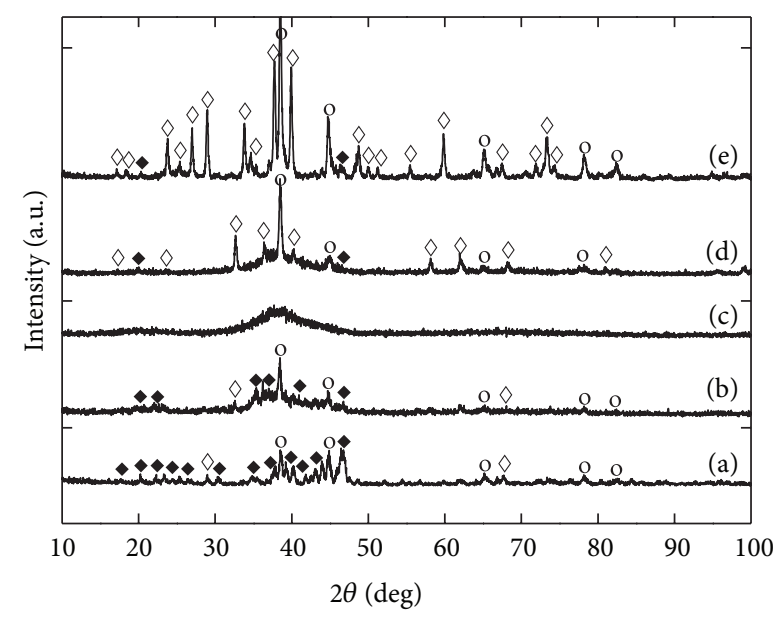

$$
\begin{array}{ll}
-\mathrm{Al}_{9} \mathrm{Co}_{2} \\
\diamond \mathrm{Al}_{3} \mathrm{Y} \\
\circ \quad \alpha-\mathrm{Al}
\end{array}
$$

FIGURE 3: XRD patterns of Al-Co-Y alloy ribbons, (a) $\mathrm{Al}_{85} \mathrm{Co}_{13} \mathrm{Y}_{2}$, (b) $\mathrm{Al}_{85} \mathrm{Co}_{10} \mathrm{Y}_{5}$, (c) $\mathrm{Al}_{85} \mathrm{Co}_{7} \mathrm{Y}_{8}$, (d) $\mathrm{Al}_{85} \mathrm{Co}_{5} \mathrm{Y}_{10}$, and (e) $\mathrm{Al}_{85} \mathrm{Co}_{2} \mathrm{Y}_{13}$.

and $\mathrm{Al}_{9} \mathrm{Co}_{2}$. Table 1 summarizes the crystallographic data obtained from the XRD analysis. As indicated by the variation of diffraction peak intensities in Figure 2, the peak intensities of the $\mathrm{Al}_{3} \mathrm{Y}$ phase grow slightly with the increasing of $\mathrm{Y}$ amount. For the alloy with 13 at.\% Y, the XRD pattern of the sample appears to be composed of mainly $\mathrm{Al}_{3} \mathrm{Y}$ and fcc-Al phases with a small amount of $\mathrm{Al}_{9} \mathrm{Co}_{2}$ phase. Similarly, with decreasing $\mathrm{Y}$ content in the $\mathrm{Al}-\mathrm{Co}-\mathrm{Y}$ alloys, the amount of $\mathrm{Al}_{3} \mathrm{Y}$ decreases, but that of $\mathrm{Al}_{9} \mathrm{Co}_{2}$ increases. In $\mathrm{Al}_{85} \mathrm{Co}_{13} \mathrm{Y}_{2}$ alloy, the diffraction pattern shows mainly the reflections of $\mathrm{Al}_{9} \mathrm{Co}_{2}$ and fcc-Al phases with a small amount of $\mathrm{Al}_{3} \mathrm{Y}$ phase. It is clear from the peak intensities that fcc $\alpha$-Al is the major phase for all alloy compositions. However, the peaks of $\alpha-\mathrm{Al}$ phase were found to be slightly shifted to lower diffraction angles with the increase of $Y$ content. This can be attributed to the change in the lattice parameters. Corresponding $\alpha-\mathrm{Al}$ lattice parameter was determined by Rietveld analysis using the Maud refinement software [25]. It was found that the lattice parameter of the $\alpha$-Al phase increased from $4.0474 \AA$ for $\mathrm{Al}_{85} \mathrm{Co}_{13} \mathrm{Y}_{2}$ to $4.0495 \AA$ for $\mathrm{Al}_{85} \mathrm{Co}_{2} \mathrm{Y}_{13}$. By taking into account nominal atomic radii of $\mathrm{Al}(1.43 \AA)$, Co $(1.25 \AA)$, and $\mathrm{Y}(1.80 \AA)$ [26], the increase of the lattice parameter of the $\alpha$ $\mathrm{Al}$ phase indicates the increase of the solubility of $\mathrm{Y}$ in the $\alpha$-Al phase. A similar behavior was observed for the Al-10Ni10Ce (wt.\%) alloy [27].

The XRD patterns of the melt-spun Al-Co-Y alloy ribbons are shown in Figure 3. The microstructures of the rapidly solidified alloys are almost different to the conventionally cast one. It is obvious that only $\mathrm{Al}_{85} \mathrm{Co}_{7} \mathrm{Y}_{8}$ alloy ribbon shows a fully amorphous structure, whereas the $\mathrm{Al}_{85} \mathrm{Co}_{13} \mathrm{Y}_{2}$ and $\mathrm{Al}_{85} \mathrm{Co}_{2} \mathrm{Y}_{13}$ alloy ribbons are fully crystalline. And the $\mathrm{Al}_{85} \mathrm{Co}_{10} \mathrm{Y}_{5}$ and $\mathrm{Al}_{85} \mathrm{Co}_{5} \mathrm{Y}_{10}$ alloy ribbons consist of some crystalline phases within an amorphous matrix, shown in Figures 3(b) and 3(d). These results indicate that the amount of crystalline phases decreases when the alloy is closer to the best glass-forming composition. Thus, the GFA of these alloys is enhanced, when the composition is away from the corresponding crystalline phases. As seen in Figure 1, the $\mathrm{Al}_{85} \mathrm{Co}_{7} \mathrm{Y}_{8}$ alloy is located at the cross junction and represents the best glass former within the studied compositional range. Around this optimum GFA composition, it is noted that there are the composite structures with primary phases of $\alpha-\mathrm{Al}$, $\mathrm{Al}_{3} \mathrm{Y}$ and $\mathrm{Al}_{9} \mathrm{Co}_{2}$. Similarly, $\mathrm{Al}_{88} \mathrm{Co}_{4} \mathrm{Y}_{8}$ and $\mathrm{Al}_{88} \mathrm{Co}_{5} \mathrm{Y}_{7}$ alloys were also reported as the best glass formers within different compositions in this triangle area [18-20]. Furthermore, it was found that the optimum glass-forming region for the Al$\mathrm{Ni}-\mathrm{RE}$ ( $\mathrm{La}, \mathrm{Ce}, \mathrm{Pr}, \mathrm{Nd}$, and $\mathrm{Mm}$ ) systems was in the center of the composites with primary phases of $\alpha-\mathrm{Al}, \mathrm{Al}_{11} \mathrm{RE}_{3}$, and $\mathrm{Al}_{3} \mathrm{Ni}$. It was verified that optimum GFA compositions in such systems are sensitive to both $\mathrm{Ni}$ and $\mathrm{RE}$ contents [28]. It can be concluded that the replacement between the alloy elements plays an important role in promoting glass formation. Moreover, the average crystallite sizes of the fcc$\mathrm{Al}$ phase were determined from the X-ray line broadening using the well-known Scherrer equation [29]. The calculated average crystallite sizes are 28.7, 32.7, 33.1, and $40.5 \mathrm{~nm}$ for the melt-spun alloy ribbons of $x=2,5,10$, and 13, respectively, as a result of the high cooling rate gained in the melt-spun technique. By the way, the melt-spun alloy ribbons including crystalline phases exhibit brittle behavior, while the meltspun amorphous alloy exhibits good bending ductility.

Figure 4 shows the cross sectional images of the melt-spun alloy ribbons. These images represent different microstructural features. $\mathrm{Al}_{85} \mathrm{Co}_{13} \mathrm{Y}_{2}$ and $\mathrm{Al}_{85} \mathrm{Co}_{2} \mathrm{Y}_{13}$ alloys display the rough and irregularly shaped domain structure with intermetallic phase precipitations. According to the XRD results of both samples, these precipitations are the $\mathrm{Al}_{3} \mathrm{Y}$ and $\mathrm{Al}_{9} \mathrm{Co}_{2}$ intermetallic phases. As seen in Figures $4(\mathrm{~b})$ and 4(d), the SEM images of the $\mathrm{Al}_{85} \mathrm{Co}_{10} \mathrm{Y}_{5}$ and $\mathrm{Al}_{85} \mathrm{Co}_{5} \mathrm{Y}_{10}$ alloys reveal the white dendritic crystalline particles, which are uniformly distributed in a featureless amorphous matrix. The SEM results exhibit the same behavior in agreement with the XRD results. As seen in Figure 4(c), the $\mathrm{Al}_{85} \mathrm{Co}_{7} \mathrm{Y}_{8}$ alloy displays the featureless morphology, which is the typical characteristic of the amorphous phase. Similar microstructural features were also reported in the literature $[6,18,20,27,28]$. Also, Figure 4(f) shows the EDX analysis of the $\mathrm{Al}_{85} \mathrm{Co}_{7} \mathrm{Y}_{8}$ alloy ribbon. From EDX analysis, the peaks of $\mathrm{Al}, \mathrm{Co}$, and $\mathrm{Y}$ are clearly seen and the percentages of element compositions are close to the nominal compositions. This indicated the minimal loss of solute elements during alloy preparation and processing.

In order to examine the crystallization and melting behavior of the melt-spun $\mathrm{Al}_{85} \mathrm{Co}_{15-x} \mathrm{Y}_{x}(x=2,5,8,10$, and 13) alloys, the DSC and DTA analyses were carried out, as shown in Figures 5 and 6, respectively. Thermal properties of these alloys, including $T_{g}$ (glass transition temperature), $T_{x}$ (onset crystallization temperature), $T_{m}$ (onset melting temperature), $T_{l}$ (liquidus temperature), and calculated GFA parameters $\left(T_{x} / T_{m}, T_{x} / T_{l}\right.$ and $\left.\Delta T_{m}\right)$ are listed in Table 2. From DSC curves, two or three exothermic peaks corresponding to the crystallization phases were observed in different temperature ranges. The $\mathrm{Al}_{85} \mathrm{Co}_{7} \mathrm{Y}_{8}$ and $\mathrm{Al}_{85} \mathrm{Co}_{5} \mathrm{Y}_{10}$ alloys undergo a three-stage crystallization process, whereas the $\mathrm{Al}_{85} \mathrm{Co}_{10} \mathrm{Y}_{5}$ 


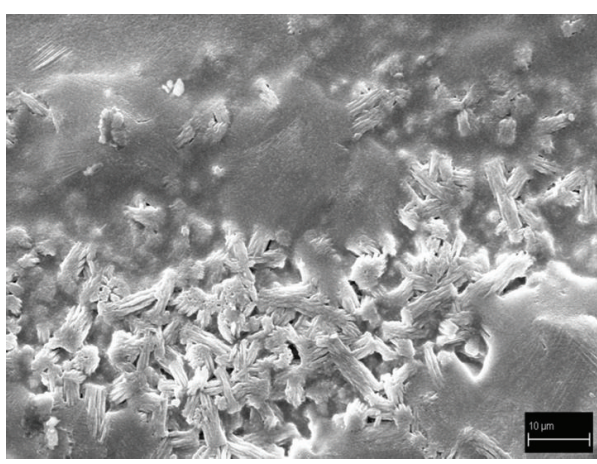

(a)

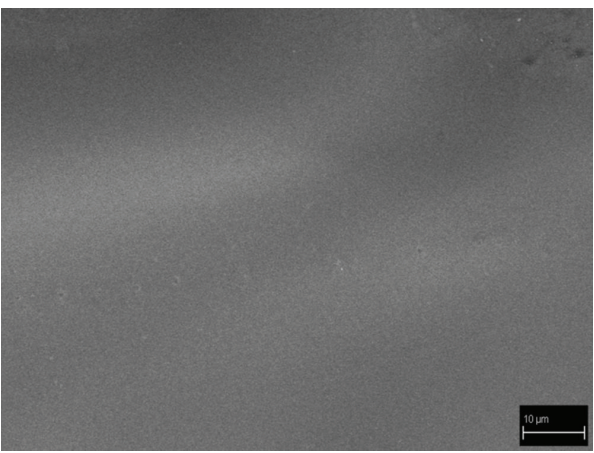

(c)

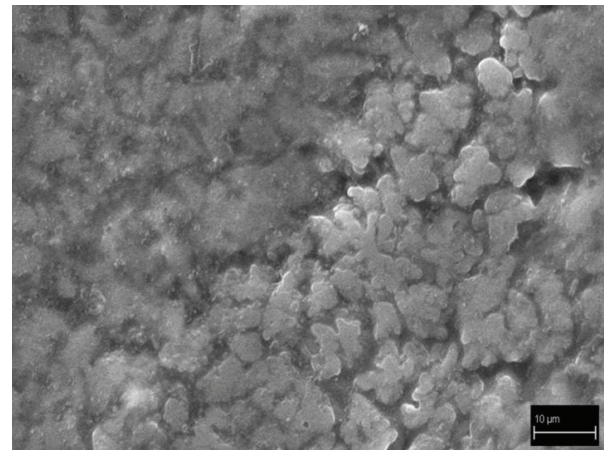

(e)

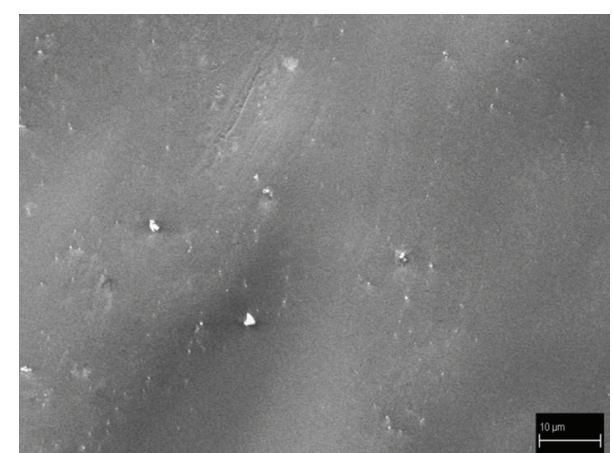

(b)

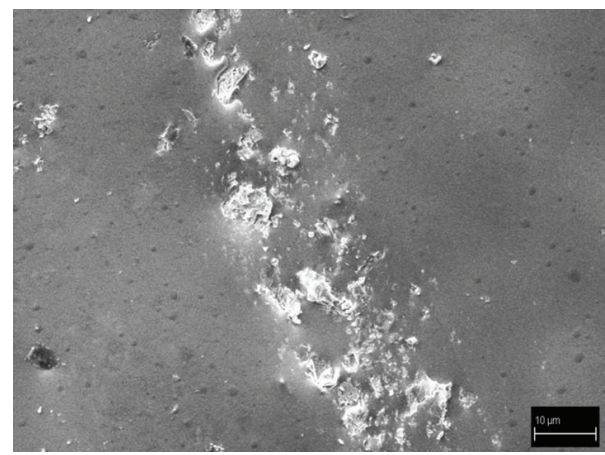

(d)

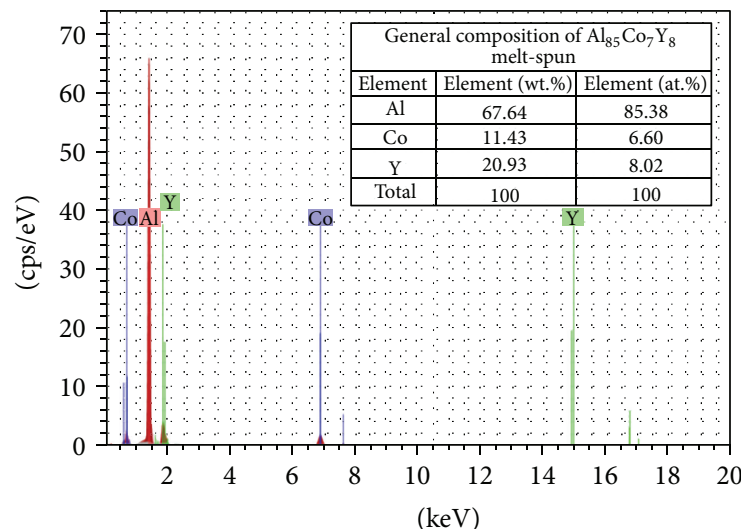

(f)

FIgURE 4: SEM images of the cross sections of the Al-Co-Y alloy ribbons: (a) $\mathrm{Al}_{85} \mathrm{Co}_{13} \mathrm{Y}_{2}$, (b) $\mathrm{Al}_{85} \mathrm{Co}_{10} \mathrm{Y}_{5}$, (c) $\mathrm{Al}_{85} \mathrm{Co}_{7} \mathrm{Y}_{8}$, (d) $\mathrm{Al}_{85} \mathrm{Co}_{5} \mathrm{Y}_{10}$, (e) $\mathrm{Al}_{85} \mathrm{Co}_{2} \mathrm{Y}_{13}$, and (f) EDX analysis of the $\mathrm{Al}_{85} \mathrm{Co}_{7} \mathrm{Y}_{8}$ alloy ribbon.

TABLE 1: Crystallographic data of phases present in the Al-Co-Y ingot alloys [24].

\begin{tabular}{lccc}
\hline Phase & Class & Space group & Lattice parameters (nm) \\
\hline$\alpha-\mathrm{Al}$ & Cubic & $F m \overline{3} m$ & $a=0.4049$ \\
$\mathrm{Al}_{3} \mathrm{Y}$ & Rhombohedral & $R \overline{3} m$ & $a=0.6195, c=2.112$ \\
$\mathrm{Al}_{9} \mathrm{Co}_{2}$ & Monoclinic & $P 21 / a$ & $a=0.8556, b=0.6290, c=0.6123$ \\
\hline
\end{tabular}

alloy undergoes a two-stage crystallization process. As seen in Figure 5, the corresponding exothermic peaks in DSC curve become wider and weaker with both the increasing and decreasing of $\mathrm{Y}$ content. Regarding this, the $\mathrm{Al}_{85} \mathrm{Co}_{13} \mathrm{Y}_{2}$ and $\mathrm{Al}_{85} \mathrm{Co}_{2} \mathrm{Y}_{13}$ alloys do not exhibit any crystallization exotherms. It can be also seen in Table 2 that the $T_{x}$ of the
$\mathrm{Al}_{85} \mathrm{Co}_{7} \mathrm{Y}_{8}$ alloy is higher than that of the other alloys. This increase in the thermal stability against devitrification can be attributed to the slight variation of solute concentration in the amorphous phase. Yang et al. [18] reported the same crystallization behavior for $\mathrm{Al}-\mathrm{Ni}-\mathrm{Y}$ and $\mathrm{Al}-\mathrm{Co}-\mathrm{Y}$ ternary alloys. However, they also noted that the best glass formers 
TABLE 2: Thermal properties of the melt-spun Al-Co-Y alloy ribbons.

\begin{tabular}{|c|c|c|c|c|c|c|c|}
\hline Alloys & $T_{g}(\mathrm{~K})$ & $T_{x}(\mathrm{~K})$ & $T_{m}(\mathrm{~K})$ & $T_{l}(\mathrm{~K})$ & $T_{x} / T_{m}$ & $T_{x} / T_{l}$ & $\Delta T_{m}(\mathrm{~K})$ \\
\hline $\mathrm{Al}_{85} \mathrm{Co}_{13} \mathrm{Y}_{2}$ & - & - & 917 & 1277 & - & - & \\
\hline $\mathrm{Al}_{85} \mathrm{Co}_{10} \mathrm{Y}_{5}$ & - & 573 & 916 & 1175 & 0.62 & 0.49 & 343 \\
\hline $\mathrm{Al}_{85} \mathrm{Co}_{7} \mathrm{Y}_{8}$ & 569 & 586 & 916 & 1180 & 0.64 & 0.50 & 330 \\
\hline $\mathrm{Al}_{85} \mathrm{Co}_{5} \mathrm{Y}_{10}$ & - & 566 & 916 & 1168 & 0.62 & 0.48 & 350 \\
\hline $\mathrm{Al}_{85} \mathrm{Co}_{2} \mathrm{Y}_{13}$ & - & - & 917 & 1133 & - & - & \\
\hline
\end{tabular}

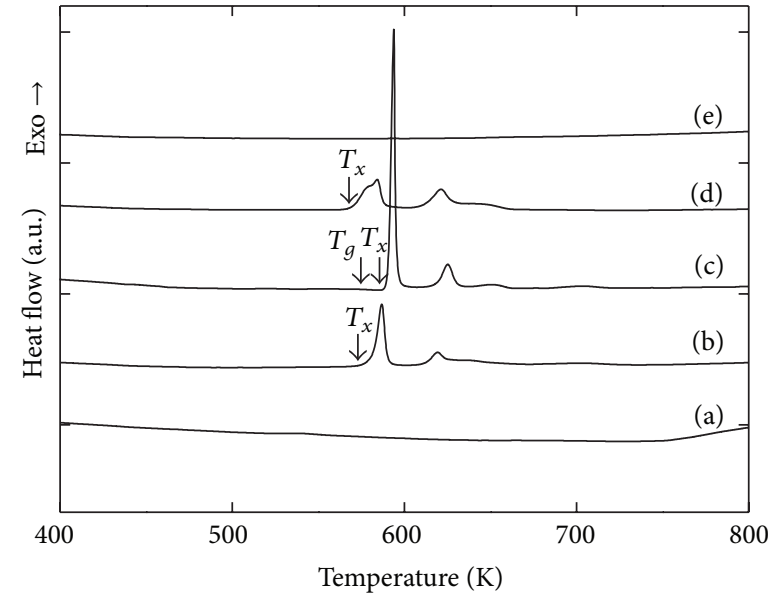

FIGURE 5: DSC curves of the Al-Co-Y alloy ribbons: (a) $\mathrm{Al}_{85} \mathrm{Co}_{13} \mathrm{Y}_{2}$, (b) $\mathrm{Al}_{85} \mathrm{Co}_{10} \mathrm{Y}_{5}$, (c) $\mathrm{Al}_{85} \mathrm{Co}_{7} \mathrm{Y}_{8}$, (d) $\mathrm{Al}_{85} \mathrm{Co}_{5} \mathrm{Y}_{10}$, and (e) $\mathrm{Al}_{85} \mathrm{Co}_{2} \mathrm{Y}_{13}$.

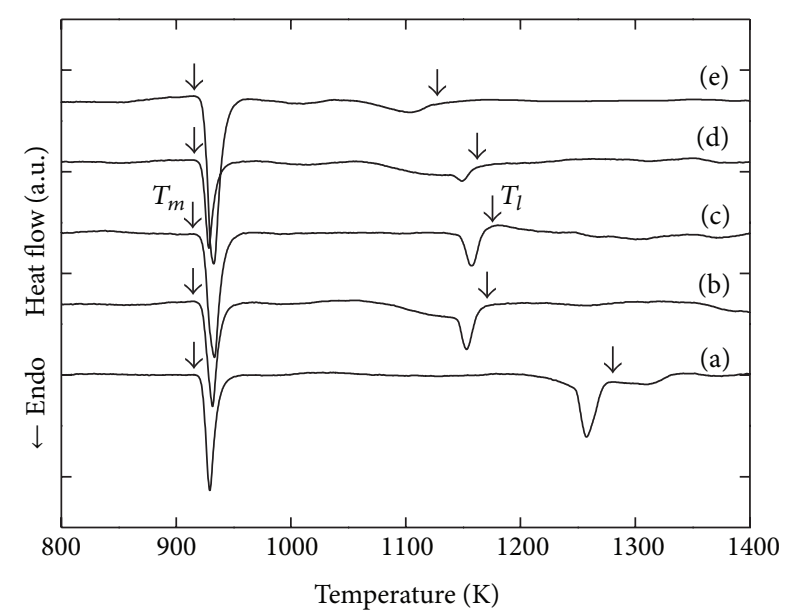

FIGURE 6: DTA curves of the Al-Co-Y alloy ribbons: (a) $\mathrm{Al}_{85} \mathrm{Co}_{13} \mathrm{Y}_{2}$, (b) $\mathrm{Al}_{85} \mathrm{Co}_{10} \mathrm{Y}_{5}$, (c) $\mathrm{Al}_{85} \mathrm{Co}_{7} \mathrm{Y}_{8}$, (d) $\mathrm{Al}_{85} \mathrm{Co}_{5} \mathrm{Y}_{10}$, and (e) $\mathrm{Al}_{85} \mathrm{Co}_{2} \mathrm{Y}_{13}$.

$\mathrm{Al}_{88} \mathrm{Ni}_{4} \mathrm{Y}_{8}$ and $\mathrm{Al}_{88} \mathrm{Co}_{4} \mathrm{Y}_{8}$ alloys did not exhibit a glass transition temperature $\left(T_{g}\right)$. It might be due to the structural relaxation on the DSC curve which could overlap with the endothermic glass transition signals. Thus, $T_{g}$ would be hidden in the DSC curve [30]. Apart from this, the chemical interaction between $\mathrm{Al}$ and the alloying elements plays an essential role in the practical GFA for the Al-based alloys [23]. In contrast, in the present study, $T_{g}$ was observed at $569 \mathrm{~K}$ in $\mathrm{Al}_{85} \mathrm{Co}_{7} \mathrm{Y}_{8}$ alloy. The glass transition behavior for amorphous alloys is of technological and scientific importance, because the $T_{g}$ reflects the atomic transport and viscosity properties which are dominant factors in the GFA of alloys and in the structural relaxation and thermal stability of the amorphous structure [31]. Moreover, A. Inoue [2] pointed out the supercooled liquid region $\left(\Delta T_{x}=T_{x}-T_{g}\right)$, which is an important parameter characterizing the thermal stability. The $\Delta T_{x}$ was found to be $17 \mathrm{~K}$ for the $\mathrm{Al}_{85} \mathrm{Co}_{7} \mathrm{Y}_{8}$ alloy, which is higher than those of other similar systems $[26,32,33]$. But, it is lower than that obtained in a similar composition range in the AlCo-Y system $[18,19]$. It is noted that $\Delta T_{x}$ is specific to the alloy composition and the heating scan rate in DSC analysis. On the other hand, it can be seen from the DTA curves that the onset melting temperature $\left(T_{m}\right)$ remains almost constant, while the liquidus temperature $\left(T_{l}\right)$ changes with the alloy composition. Using the $T_{g}$ and $T_{l}$ values, the reduced glass transition temperature $T_{r g}\left(=T_{g} / T_{l}\right)$ was estimated to be about 0.48 for the $\mathrm{Al}_{85} \mathrm{Co}_{7} \mathrm{Y}_{8}$. It was reported that in Al-based amorphous alloys with high $\mathrm{Al}$ content (>80 at.\%), the $T_{r g}$ values are generally less than 0.5 [34]. As seen in Table 2, $T_{x} / T_{m}, T_{x} / T_{l}$, and $\Delta T_{m}\left(=T_{m}-T_{x}\right)$ were also calculated. And, it is proved that in some amorphous alloy systems, higher $T_{x} / T_{m}$ and lower $\Delta T_{m}$ usually correspond to better GFA. Moreover, the alloy with a higher $T_{x} / T_{l}$ parameter more likely has a better GFA $[32,35]$. According to these criterions and the calculated GFA parameters listed in Table 2, the $\mathrm{Al}_{85} \mathrm{Co}_{7} \mathrm{Y}_{8}$ alloy has a better GFA compared to previously reported values $[32,35]$.

\section{Conclusions}

In the present study, the $\mathrm{Al}_{85} \mathrm{Y}_{x} \mathrm{Co}_{15-x}(x=2,5,8,10$, and 13 at.\%) alloys were prepared by conventional casting and meltspinning technique. The microstructure of the master alloy ingots was composed of three different phases, fcc $\alpha-\mathrm{Al}_{2} \mathrm{Al}_{3} \mathrm{Y}$, and $\mathrm{Al}_{9} \mathrm{Co}_{2}$. It was also indicated that, the solubility of $\mathrm{Y}$ in the $\alpha$-Al phase increased with the increasing of Y amount. However, the XRD and SEM results of the melt-spun alloys revealed that only $\mathrm{Al}_{85} \mathrm{Co}_{7} \mathrm{Y}_{8}$ have a fully amorphous structure, whereas crystalline phases were detected in others. Also, the amount of the crystalline phases decreases when the alloy is closer to the best glass-forming composition. Moreover, the melt-spun alloy ribbons including crystalline phases were brittle, whereas the melt-spun amorphous alloy was ductile. From the thermal analysis, the $\mathrm{Al}_{85} \mathrm{Co}_{7} \mathrm{Y}_{8}$ amorphous alloy was found to be the most thermally stable. Also, some GFArelated parameters, such as $T_{x} / T_{m}, T_{x} / T_{l}$, and $\Delta T_{m}$, were calculated. It was found that the $\mathrm{Al}_{85} \mathrm{Co}_{7} \mathrm{Y}_{8}$ alloy had a better 
GFA, and it could be explained by the increased thermal stability.

\section{Acknowledgments}

The authors would like to thank Kahramanmaras Sutcu Imam University for the financial support of the research program (Project no. 2011/3-42 D) and TUBITAK-BIDEP postdoctoral research fellowship.

\section{References}

[1] Y. He, S. J. Poon, and G. J. Shiflet, "Synthesis and properties of metallic glasses that contain aluminum," Science, vol. 241, no. 4873, pp. 1640-1642, 1988.

[2] A. Inoue, "Amorphous, nanoquasicrystalline and nanocrystalline alloys in Al-based systems," Progress in Materials Science, vol. 43, no. 5, pp. 365-520, 1998.

[3] A. Inoue, "Stabilization of metallic supercooled liquid and bulk amorphous alloys," Acta Materialia, vol. 48, no. 1, pp. 279-306, 2000.

[4] M. Gögebakan, "Crystallization studies of $\mathrm{Al}_{85} \mathrm{Y}_{10} \mathrm{Fe}_{5-x} \mathrm{Nix}$ $(x=0,2.5,5)$ alloys," Journal of Materials Engineering and Performance, vol. 12, no. 5, pp. 521-523, 2003.

[5] M. Gögebakan, "The effect of Si addition on crystallization behavior of amorphous Al-Y-Ni alloy," Journal of Materials Engineering and Performance, vol. 13, no. 4, pp. 504-508, 2004.

[6] J. He, H. Jiang, J. Zhao, N. Mattern, and J. Eckert, "AlNiYCo amorphous matrix composites induced by bismuth and lead additions," Metallurgical and Materials Transactions A, vol. 42, no. 13, pp. 4100-4105, 2011.

[7] M. Gogebakan, P. J. Warren, and B. Cantor, "Crystallization behaviour of amorphous $\mathrm{Al}_{85} \mathrm{Y}_{11} \mathrm{Ni}_{4}$ alloy," Materials Science and Engineering A, vol. 226-228, pp. 168-172, 1997.

[8] W. T. Kim, M. Gogebakan, and B. Cantor, "Heat treatment of amorphous $\mathrm{Al}_{85} \mathrm{Y}_{5} \mathrm{Ni}_{10}$ and $\mathrm{Al}_{85} \mathrm{Y}_{10} \mathrm{Ni}_{5}$ alloys," Materials Science and Engineering A, vol. 226-228, pp. 178-182, 1997.

[9] S.-F. Chen, J.-K. Chen, S.-L. Lin, and Y.-L. Lin, "Effects of B upon glass forming ability of $\mathrm{Al}_{87} \mathrm{Y}_{8} \mathrm{Ni}_{5}$ amorphous alloy," Journal of Alloys and Compounds, vol. 565, pp. 29-36, 2013.

[10] K. L. Sahoo, M. Wollgarten, K. B. Kim, and J. Banhart, "Crystallization behavior and microhardness evolution in $\mathrm{Al}_{92-x} \mathrm{Ni}_{8} \mathrm{La}_{x}$ amorphous alloys," Journal of Materials Research, vol. 20, no. 11, pp. 2927-2933, 2005.

[11] G. Li, W. Wang, X. Bian et al., "Influences of similar elements on glass forming ability and magnetic properties in Al-Ni-La amorphous alloy," Journal of Materials Science and Technology, vol. 26, no. 2, pp. 146-150, 2010.

[12] G. H. Li, W. M. Wang, H. J. Ma et al., "Effect of different annealing atmospheres on crystallization and corrosion resistance of $\mathrm{Al}_{86} \mathrm{Ni}_{9} \mathrm{La}_{5}$ amorphous alloy," Materials Chemistry and Physics, vol. 125, no. 1-2, pp. 136-142, 2011.

[13] A. Inoue, N. Matsumoto, and T. Masumoto, "Al-Ni-Y-Co amorphous alloys with high mechanical strengths, wide supercooled liquid region and large glass-forming capacity," Materials Transactions, vol. 31, no. 6, pp. 493-500, 1990.

[14] N. Bassim, C. S. Kiminami, M. J. Kaufman, M. F. Oliveira, M. N. R. V. Perdigao, and W. J. Botta Filho, "Crystallization behavior of amorphous $\mathrm{Al}_{84} \mathrm{Y}_{9} \mathrm{Ni}_{5} \mathrm{Co}_{2}$ alloy," Materials Science and Engineering A, vol. 304-306, no. 1-2, pp. 332-337, 2001.
[15] D. V. Louzguine-Luzgin, "Aluminum-base amorphous and nanocrystalline materials," Metal Science and Heat Treatment, vol. 53, no. 9-10, pp. 472-477, 2012.

[16] A. Inoue, K. Ohtera, A.-P. Tsai, and T. Masumoto, "New amorphous alloys with good ductility in Al-Y-M and Al-La-M $(\mathrm{M}=\mathrm{Fe}, \mathrm{Co}, \mathrm{Ni}$ or $\mathrm{Cu}$ ) systems," Japanese Journal of Applied Physics, vol. 27, no. 3, pp. L280-L282, 1988.

[17] J. Latuch and W. Dmowski, "Glass-formation in $\mathrm{Al}_{85} \mathrm{Y}_{10}(\mathrm{Fe}, \mathrm{Co}$, $\mathrm{Ni}, \mathrm{Cu})_{5}$ alloys," Key Engineering Materials, vol. 81-83, pp. 129134, 1993.

[18] H. W. Yang, P. Dong, J. Q. Wang, and Y. Li, "Glass formability and structural stability of Al-based alloy systems," Materials Science and Engineering A, vol. 448-451, pp. 273-276, 2007.

[19] P. Dong, J. Zhang, X. Chang, W. Hou, M. Quan, and J. Wang, "Amorphous phase formation and microstructure evolution in the Al-rich region of Al-Co-Y system," Acta Metallurgica Sinica, vol. 44, no. 2, pp. 227-232, 2008.

[20] P. Dong, J. Zhang, W. Hou, X. Chang, J. Wang, and M. Quan, "Investigation of glass formability in Al-Co-Y ternary system," Journal of Materials Science and Technology, vol. 24, no. 2, pp. 161-164, 2008.

[21] D. Wang, Y. Li, B. B. Sun, M. L. Sui, K. Lu, and E. Ma, "Bulk metallic glass formation in the binary $\mathrm{Cu}-\mathrm{Zr}$ system," Applied Physics Letters, vol. 84, no. 20, pp. 4029-4031, 2004.

[22] D. Wang, H. Tan, and Y. Li, "Multiple maxima of GFA in three adjacent eutectics in $\mathrm{Zr}-\mathrm{Cu}-\mathrm{Al}$ alloy system-a metallographic way to pinpoint the best glass forming alloys," Acta Materialia, vol. 53, no. 10, pp. 2969-2979, 2005.

[23] J.-H. Jun, J.-M. Kim, K.-T. Kim, and W.-J. Jung, "Glass formability and thermal stability of Al-Ni-Y-Be amorphous alloys," Journal of Alloys and Compounds, vol. 434-435, pp. 190-193, 2007.

[24] JCPDS Database, International Center for Diffraction Data, Swarthmore, USA, PDF 04-0787, PDF 03-065-3698, PDF 060699.

[25] L. Lutterotti, “MAUD," CPD Newsletter IUCr no. 24, 2000.

[26] J. G. Speight, Lange's Handbook of Chemistry, McGraw-Hill, New York, NY, USA, 2005.

[27] E. M. Ahmed, "The influence of rapid solidification on the microstructure properties of Al-10Ni-10Ce alloy," The European Physical Journal Plus, vol. 127, article 70, 2012.

[28] H. Yang, J. Q. Wang, and Y. Li, "Glass formation and microstructure evolution in Al-Ni-RE ( $\mathrm{RE}=\mathrm{La}, \mathrm{Ce}, \mathrm{Pr}, \mathrm{Nd}$ and misch metal) ternary systems," Philosophical Magazine, vol. 87, no. 27, pp. 4211-4228, 2007.

[29] B. D. Cullity and S. R. Stock, Elements of X-Ray Diffraction, Prentice Hall, Upper Saddle River, NJ, USA, 3rd edition, 2001.

[30] H. W. Yang, M. J. Tan, R. D. Li, and J. Q. Wang, "Effect of minor $\mathrm{V}$ addition on $\mathrm{Al}_{88} \mathrm{Y}_{7} \mathrm{Fe}_{5}$ amorphous alloys," Applied Mechanics and Materials, vol. 302, pp. 76-81, 2013.

[31] M. Gogebakan, I. Karteri, B. Avar, and C. Kursun, "Crystallization behavior of Mg-Cu-Y amorphous alloy," Journal of Thermal Analysis and Calorimetry, vol. 110, no. 2, pp. 793-798, 2012.

[32] C. Triveño Rios, S. Suriñach, M. D. Baró, C. Bolfarini, W. J. Botta, and C. S. Kiminami, "Glass forming ability of the Al-CeNi system," Journal of Non-Crystalline Solids, vol. 354, no. 42-44, pp. 4874-4877, 2008.

[33] J. G. Lin, W. W. Wang, X. Q. Wu, J. H. Lei, and S. Yin, "Crystallization and corrosion resistance of as-spun $\left(\mathrm{Al}_{86} \mathrm{Ni}_{9} \mathrm{La}_{5}\right)_{98} \mathrm{Zr}_{2}$ amorphous alloy," Journal of Alloys and Compounds, vol. 478, no. 1-2, pp. 763-766, 2009. 
[34] J. Q. Wang, P. Dong, W. L. Hou, X. C. Chang, and M. X. Quan, "Synthesis of Al-rich bulk metallic glass composites by warm extrusion of gas atomized powders," Journal of Alloys and Compounds, vol. 554, pp. 419-425, 2013.

[35] G. Li, X. Bian, K. Song, J. Guo, X. Li, and C. Wang, "Effect of Si addition on glass forming ability and thermal stability of Al-FeLa alloys," Journal of Alloys and Compounds, vol. 471, no. 1-2, pp. L47-L50, 2009. 

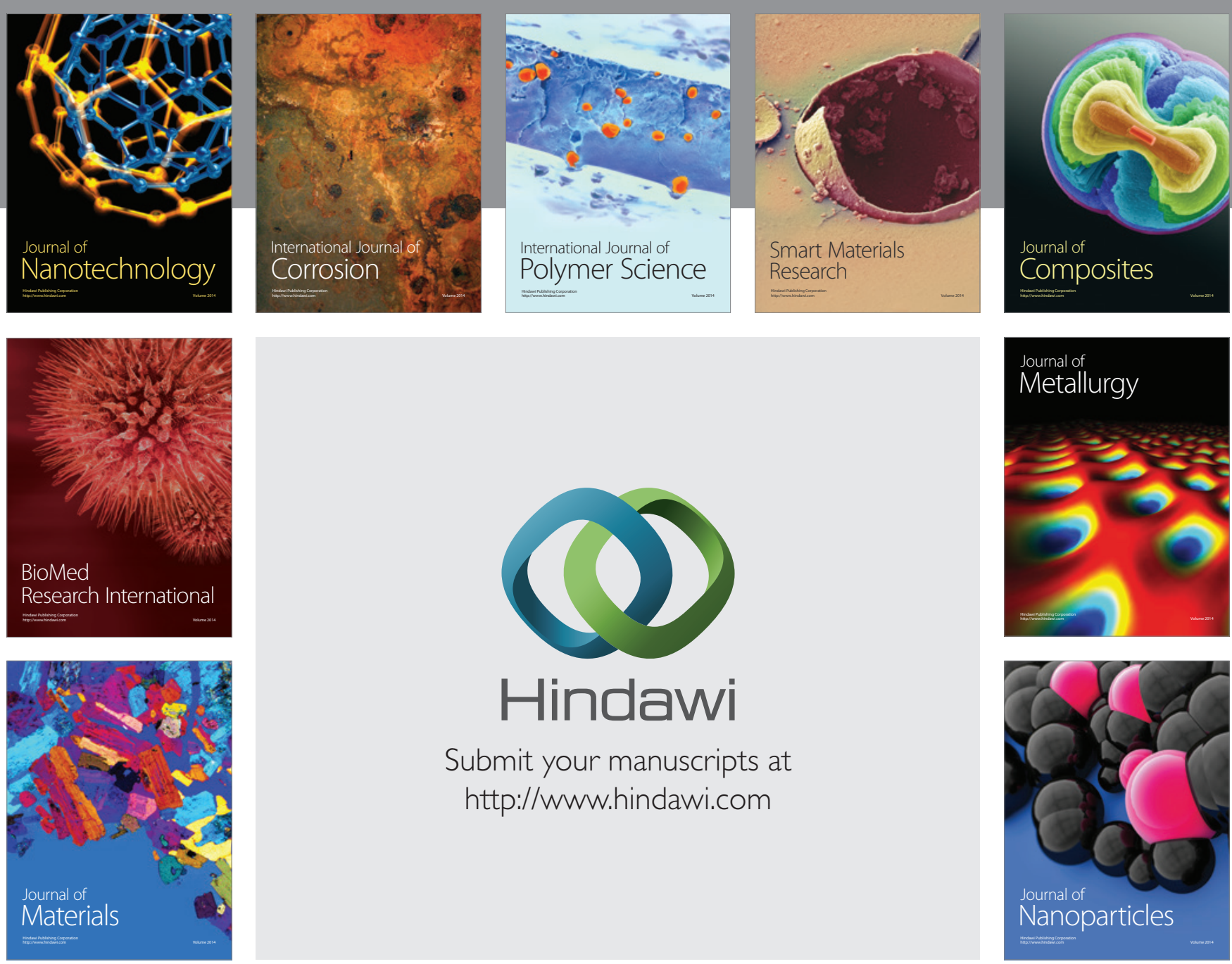

Submit your manuscripts at http://www.hindawi.com
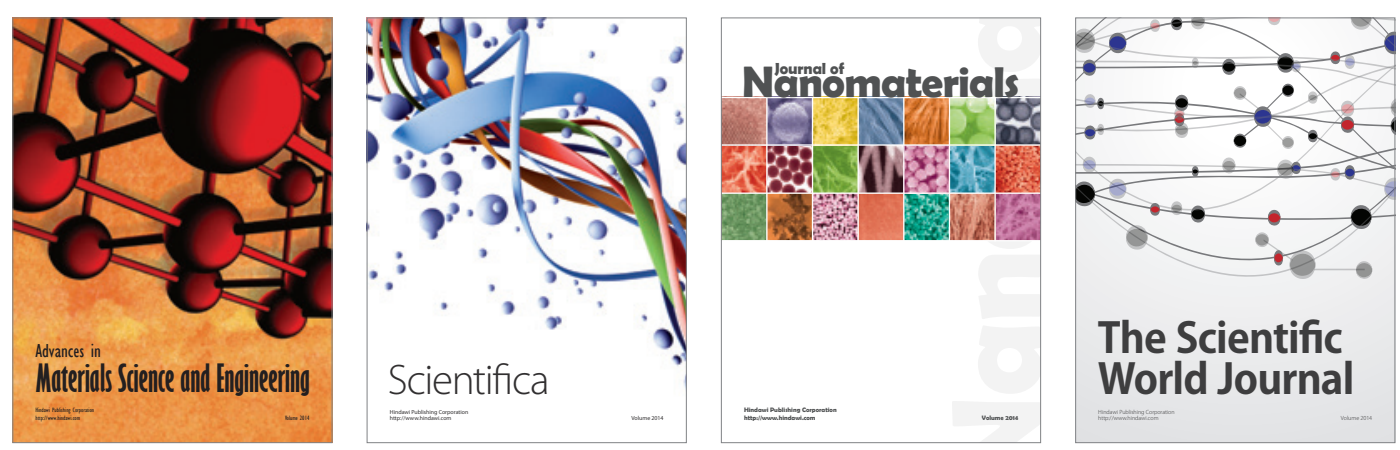

\section{The Scientific World Journal}
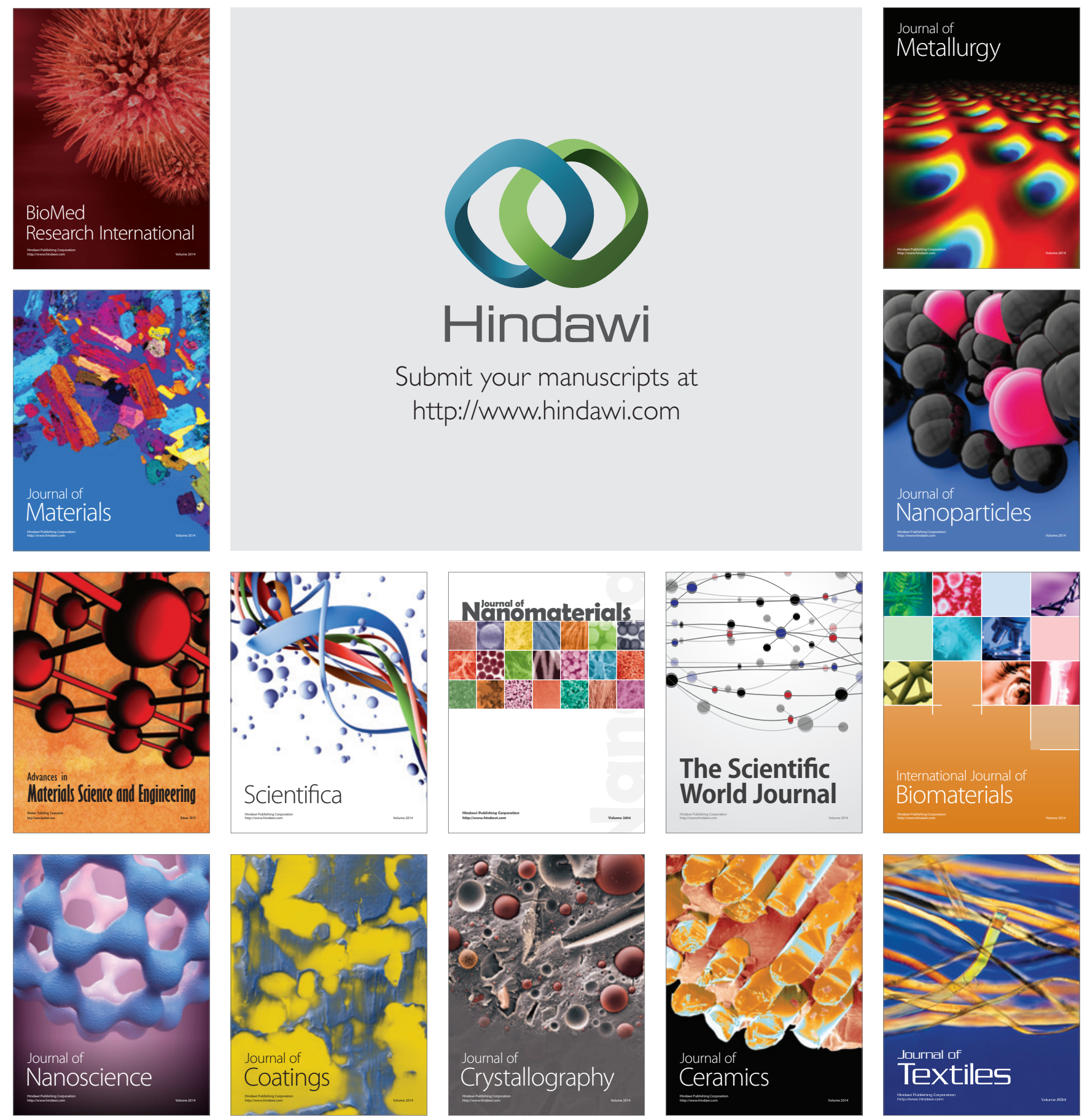